IVANa ČagalJ

FILOZOFSKI FAKULTET SveuČILIŠTA U ZaGREBU

Zagreb, HRVATSKa

icagalj@ffzg.hr

Milina SvítKová

FILOZOFSKI fakUltet SVEUČILIŠta Komenskog u BratislaVI

Bratislava, SlovačKa

milina.svitkova@uniba.sk

https://doi.org/10.17234/9789531755139.3

\title{
TIPOLOGIJA FRAZEOLOŠKE EKVIVALENCIJE NA PRIMJERU HRVATSKIH I SLOVAČKIH FRAZEMA S IHTIONIMSKOM SASTAVNICOM
}

\begin{abstract}
Polazeći od konvergentnih tipologija međujezične ekvivalencije razrađenih u hrvatskoj i slovačkoj frazeologiji, u radu se definiraju i analiziraju oblici podudarnosti hrvatskih i slovačkih frazema s ihtionimskom sastavnicom. S obzirom na stupanj istovrijednosti strukturnih, semantičkih, funkcionalno-stilističkih i dr. obilježja frazeoloških jedinica, razlikuju se četiri osnovna tipa ekvivalencije: (i) potpuna, (ii) djelomična, (iii) samo semantička i (iv) nulta. Osim višeslojne analize frazeološke ekvivalencije odabranoga korpusa, pozornost se posvećuje i kontrastiranju kulturoloških uvjetovanosti ihtionimskih frazeoloških fondova hrvatske (mediteranske, maritimne) i slovačke (srednjoeuropske, kontinentalne) jezične zajednice. Potonja se kulturološka diferenciranost prvenstveno reflektira u nacionalno i lokalno specifičnim frazemima s hiponimskom ihtionimskom sastavnicom, odnosno, u frazeološkim strukturama koje sadrže naziv određene morske ili riječne ribe, dok hiperonimski dio korpusa uglavnom predstavljaju frazemi koji su potpuni ili djelomični ekvivalenti i dio internacionalnoga frazeološkog fonda.
\end{abstract}

Ključne riječi: frazem, ihtionimska sastavnica, ekvivalencija, hrvatska frazeologija, slovačka frazeologija

\section{Uvodna bilješka o frazeološkoj ekvivalenciji}

Na temelju leksikografske, translatološke i lingvodidaktičke refleksije o asimetričnosti frazeoloških fondova pojedinih jezika te interdisciplinarnih kontaktnolingvističkih istraživanja, u okviru frazeologije konstituiralo se posebno područje kontrastivnih analiza čijim je središnjim pojmom upravo ekvivalencija. Pod potonjom se kategorijom općenito podrazumijeva odnos dvaju ili više lingvističkih entiteta koji se na temelju postojanja (kompleksa) relevantnih zajedničkih obilježja konceptualiziraju kao istovrijedni u određenom aspektu (usp. npr. Dolník 1999: 47).

Polazištem kontrastiranja frazema različitih jezika prije svega su formalna i semantička struktura, ali i dubinska slika uspoređivanih jedinica. Osim sukladnosti na planu 
izraza i značenja, ${ }^{1}$ ključnim čimbenikom u tipologiji frazeološke ekvivalencije stoga je i mjera podudarnosti slikovitosti uspoređivanih frazema. Na temelju dosadašnjih podjela, te s obzirom na prisutnost, odnosno, odsutnost, navedenih relevantnih kriterija, mogu se izdvojiti sljedeća četiri tipa frazeološke ekvivalencije: (i) potpuna (apsolutna), (ii) djelomična (parcijalna), (iii) samo semantička te (iv) nulta ekvivalencija.

\subsection{Potpuna ekvivalencija}

U skupinu potpunih, odnosno, apsolutnih, ekvivalenata ubrajaju se frazeološke jedinice koje se podudaraju u svim kriterijima, tj. strukture koje, osim identične semantike, bivaju istovrijednima i na razini slikovitosti, ali i na planu izraza. Takvi frazemi, dakle, imaju isti leksički sastav i gramatička obilježja te su motivirani jednakom slikovitošću, a prema Ďurči (1989: 35), ekvivalentni su i na stilističkoj razini.

Većinu jedinica ove skupine tvore europeizmi, odnosno, internacionalizmi. Posrijedi su frazemi čije zajedničko podrijetlo seže u kulturnu baštinu šire ili uže shvaćenoga europskog prostora, odnosno, u antička vremena i starovjekovnu mitologiju, biblijsku predaju, stariju književnost ili pak historiografiju, usp. kao furija [ući, izići i sl.] - ako fúria [vojst', vyjst' a pod.]; Sodoma i Gomora - Sodoma a Gomora i dr. Osim toga, može biti riječ i o frazemima preuzetima iz drugih jezika ili pak onima koji su dijelom opsežnijih koncepata, poput primjerice svirati prvu violinu - hrat' prvé husle; nalikovati (sličiti) < komu> kao jaje jajetu - podobat'sa ako vajce vajcu i dr. Frazemi koji pripadaju ovom tipu ekvivalencije nerijetko počivaju na identičnom načinu mišljenja, odnosno, generalizirajućem prosuđivanju životnoga tijeka, vrednovanju prirodnih pojava, ljudskih osobina, emocionalnih iskaza, imovinskih prilika, društvenih razlika i sl. (Dobríková 2010: 90), a ponekad su motivirani zajedničkim stereotipnim predodžbama pripadnika različitih jezičnih zajednica, kao npr. piti kao Rus - pit' ako Rus, pušiti kao Turčin-fajčit' ako Turek i dr.

Iako pojedini frazeolozi (usp. npr. Duurčo 1989: 35, Dobríková 2010: 90 i dr.) u slučaju postojanja identične slikovitosti u okviru potpune frazeološke ekvivalencije dopuštaju i određenu mjeru formalnoga razlikovanja, čini se da je takve jedinice ipak uputno uvrstiti među parcijalne frazeološke ekvivalente.

\subsection{Djelomična ekvivalencija}

Kontrastiranje frazema dvaju ili više jezika obično rezultira relativno malim brojem potpuno identičnih jedinica, dok su mnogo češći frazemi među kojima postoje manja ili veća odstupanja na formalnom, semantičkom, stilističkom, pragmatičkom, motivacijskom i/ili nekom drugom jezičnom planu (Mlacek 2008: 25). Drugi tip ekvivalencije stoga tvore semantički podudarni frazemi koji imaju jednaku ili vrlo sličnu slikovitost, odnosno, identičnu motivaciju, ali se formalno razlikuju na jedan od sljedećih načina:

Na temelju čisto semantičkoga kriterija obično se izdvajaju tri tipa frazeološke ekvivalencije: (i) potpuna, (ii) djelomična i (iii) nulta (usp. Mlacek et al. 1995, Dobríková 2010, Jankovičová 2013, Korhonen 2007 i dr.). 
a) Nepodudarnosti leksičkoga sastava. Određena frazeološka sastavnica ishodišnoga jezika u uspoređivanom jeziku može biti nadomještena sinonimom ili leksemom istoga semantičkog polja, npr. bježati od koga, čega kao đavo od tamjana-utekat' pred kým, čím ako čert pred svätenou vodou; ide kao po loju što - ide ako po masle čo i dr. Frazeološke sastavnice, međutim, mogu biti i semantički udaljene, pri čemu može doći i do određenih stilističkih pomaka, ali ne i do bitnih razilaženja u značenju uspoređivanih frazema, npr. pijan kao zemlja-opitý ako delo (hrv. top); jasno kao pekmez - jasné ako facka (hrv. šamar) i dr. Ovdje spadaju i primjeri u kojima frazeološkoj sastavnici u jednom jeziku odgovara značenjski bliska, ali gramatički kategorijalno različita komponenta, npr. tišina kao u grobu - ticho ako v hrobe, ide kao podmazano što - ide ako po masle čo i dr.

b) Morfološke (tvorba riječi i oblika) i ortografske nepodudarnosti. Frazeološke se komponente, naime, mogu razlikovati u gramatičkom rodu, poput gol (siromašan) kao crkveni miš - chudobný (biedny) ako kostolná myš; debeo kao prasac-tučný ako prasa, zatim u padežu, odnosno, prijedložnoj rekciji, npr. čitati koga kao <otvorenu> knjigu - čitat' v kom ako v <otvorenej> knihe; nestati (iščeznuti, rasprsnuti se) kao mjehur (mjehurić) od sapunice - prasknút' (spl'asnút') ako <mydlová> bublina, ili pak prisutnošću, odnosno, odsutnošću deminutiva, što je posebno često u hrvatsko-slovačkim usporedbama, kao npr. <to je> kuća od karata-domček z karát; marljiv kao mrav-usilovný (pilný) ako mravček. Od morfoloških, znatno su rjeđe ortografske razlike, ${ }^{2}$ npr. znati kao očenaš što - vediet’ ako Otčenáš čo; sam bog <to > zna - Boh <sám> vie.

c) Sintaktičke nepodudarnosti. U ovom tipu djelomične frazeološke ekvivalencije najčešće dolazi do promjene redoslijeda sastavnica, uglavnom u okviru determinativne i koordinativne sintagme, npr. to je $<$ kao $>$ Sveto pismo $<$ za koga $>-$ to je $<a k o>$ Písmo sväté <pre koho>; dušom i tijelom - telom a dušou.

d) Strukturne nepodudarnosti, odnosno, razlike u broju sastavnica frazeoloških jedinica. Frazemi s jednakom slikovitošću mogu se, naime, međusobno razlikovati opsegom (prošireni, odnosno, suženi oblik frazema) i prisutnošću fakultativnih ili varijantnih članova, npr. kao ćorava kokoš [naići na što, naći što itd.] - ako slepá kura $k$ zrnu [dostat' sa $k$ čomu, príst' $k$ čomu a pod.], stajati (ukipiti se) kao lipov (drveni) svetac - stát' ako svätý za dedinou i dr.

Relativno čestom pojavom u okviru djelomične ekvivalencije je i kombinacija navedenih nepodudarnosti, pri čemu može doći do, npr. više različitih odstupanja na morfološkoj razini, usp. gledati (buljiti) kao tele $<u$ šarena vrata $>-$ hl'adiet' (pozerat' $<s a>$ ) ako tel'a na nové (mal'ované) vráta; zatim kombinacije leksičkih i morfoloških otklona, usp. <potreban> kao komad kruha - potrebovat' niečo ako sol; ili nepodudarnosti leksičkih i strukturnih planova usp. suh kao komarac - tlstý ako komár <pod kolenom>.

Iako se i prema hrvatskoj ortografskoj normi Očenaš i Bog pišu velikim početnim slovom, u hrvatskoj je frazeologiji prihvaćeno pravilo da se potpuno desemantizirane sastavnice, kao što je u ovom slučaju prelazak navedenih onima u apelative, pišu malim početnim slovom (usp. Fink 2001). 


\subsection{Samo semantička ekvivalencija ${ }^{3}$}

Za razliku od većine tipologija frazeološke ekvivalencije, ${ }^{4} \mathrm{u}$ okviru predložene podjele izdvaja se i posebna skupina frazema koji imaju samo (približno) jednako značenje. Značenje se takvih frazema, naime, iskazuje različitim komponentama te je u skladu s tim motivirano različitom slikovitošću. Iako čisto semantički ekvivalenti pokazuju stanovitu sličnost $\mathrm{s}$ nultom ekvivalencijom $\mathrm{u}$ vidu nepodudarnosti leksika i slikovitosti, za razliku od potonjih, prijevodne ekvivalente imaju u frazeološkim, a ne opisnim strukturama, usp. biti (razlikovati se) kao bog i šeširdžija - to je ako sto (tisic) a jeden; to je kao gluhomu dobro jutro - <to je > ako hrach na stenu hádzat' i dr. S kontrastivno-lingvističkoga, te posebno translatološkoga aspekta, razlikovanje samo semantički ekvivalentnih i bezekvivalentnih frazeoloških jedinica čini se opravdanim.

\subsection{Nulta ekvivalencija}

Posljednju skupinu tvore bezekvivalentni frazemi, odnosno, strukture jedinstvenoga značenja kojima se u frazeološkom fondu kontrastiranoga jezika ne može pronaći pandan. Frazeološko se značenje bezekvivalentnih jedinica u drugom jeziku obično izražava ekspresivnim jednorječnim izrazima, sintagmatskim strukturama, slobodnim svezama riječi ili pak parafrazom (Jankovičová 2013: 188). Nulta frazeološka ekvivalencija obuhvaća jedinice s različitim stupnjem anomalije, odnosno, značenjski netransparentne sveze riječi eksplicitno ili implicitno povezane sa sociokulturnim kontekstom ishodišnoga jezika (Dobríková 2010: 93). Najčešće je riječ o izvornim frazemima povezanima s materijalnom i duhovnom kulturom govornika određenoga jezika (Čižmárová 2001: 114) koji su karakteristični samo za jedan od uspoređivanih jezika, npr. putovati kao kofer-0,0-srdce ako zvon i dr. Bezekvivalentni frazemi također mogu označavati i stereotipe karakteristične samo za određenu jezičnu zajednicu, usp. dužan kao Grčka - 0, buniti se kao Grk u hapsu-0 i dr.

\section{Ekvivalencija hrvatskih i slovačkih frazema s ihtionimskom sastavnicom}

Izložena četverodijelna tipologija frazeološke ekvivalencije primjenjuje se u analizi oblika i stupnja podudarnosti hrvatskih i slovačkih frazema s ihtionimskom sastavnicom. Izbor frazema s ihtionimskom sastavnicom za predmet kontrastivne analize motiviran je pretpostavkom o kulturološki motiviranoj diferenciranosti ovoga segmenta hrvatske i slovačke animalističke frazeologije. Dok je dio kulturno heterogene hrvatske jezične zajednice, naime, uključen u maritimni mediteranski kon-

3 Emilija Nedkova (2003: 81) ovaj tip ekvivalenata naziva frazeološkim analozima definirajući ih kao sinonimne jedinice s potpuno ili djelomično diferenciranom slikovitošću.

4 U većini tipologija frazeološke ekvivalencije obično se izdvajaju tri vrste, tj. apsolutna, parcijalna i nulta ekvivalencija (usp. npr. Dobríková 2010, Jankovičová 2013 i dr.), ili samo dva tipa, tj. potpuna i djelomična (usp. npr. Vidović Bolt 2004 i dr.). 
tekst, slovačka je kultura u cijelosti orijentirana kontinentalnom srednjoeuropskom kompleksu, što na određeni način potvrđuje i prikupljeni korpus frazema s ihtionimskom sastavnicom. Budući da je u lingvističkom smislu maritimna mediteranska komponenta hrvatske kulture uglavnom ograničena na priobalne čakavske i rjeđe štokavske nestandardne idiome, analizom su obuhvaćeni i određeni dijalektni frazemi koji potvrđuju maritimno frazeološko bogatstvo organskih dijalekata. Navedeno proširivanje analitičkoga interesa i na dijalektne frazeološke jedinice u ovom je slučaju nužno za cjelovitije kontrastiranje ihtionimskih frazema s lingvističkoga i kulturološkoga aspekta. Korpus kontrastiranih frazema stoga je uglavnom ekscerpiran iz općih, a u hrvatskom slučaju i dijalektnih, te frazeoloških jednojezičnih, dvojezičnih i višejezičnih rječnika navedenih u popisu literature, dok je dio jedinica obrađen u frazeološkim člancima citiranima u tekstu, ali i prikupljen korištenjem mrežnoga pretraživača Google $(\mathrm{G})$. U potonjem su slučaju najčešće posrijedi okazionalizmi u procesu frazeologizacije.

Prilikom uspoređivanja jedinica hrvatskoga i slovačkoga frazeološkog fonda nužno je uzeti u obzir i definirane granice, odnosno, opseg frazeologije u određenoj nacionalnoj filologiji. Za razliku od Zagrebačke frazeološke škole koja najmanjom strukturnom jedinicom smatra fonetsku riječ, slovačka frazeologija raspolaže i manjim konstrukcijskim jedinicama. U potonjoj se tradiciji, naime, frazemima smatraju i strukture sastavljene isključivo od nepunoznačnih riječi (tzv. supfrazemi), npr. $a \check{z}-a \check{z}$, len $c \check{i}$; ili pak jednokomponentne jedinice (tzv. jednorječni frazemi), npr. prišit' niekomu niečo, začat' si s niekým, koje se u hrvatskom jezikoslovlju definiraju kao leksičke jedinice proširenoga semantičkog polja. S obzirom na inherentno diferenciranu ekstenzivnost dviju frazeoloških koncepcija, koju valja respektirati, a ne pokušavati preslikavati jedan model na drugi, može se konstatirati da sa stajališta strukturne tipologije slovačkim supfrazemima i jednorječnim frazemima u hrvatskom frazeološkom fondu nije moguće izdvojiti apsolutne ekvivalente koji bi u nacionalnoj filologiji bili definirani kao frazeološke jedinice. U slučaju drugih strukturnih tipova zastupljenih u objema koncepcijama može se govoriti o razmjerno visokom stupnju, genetsko-tipološkom bliskošću uvjetovane, međujezične frazeološke ekvivalencije.

Budući da voda kao prirodno stanište ribljih vrsta pokriva 3/4 zemljine površine, većina svjetske populacije od davnine je u (ne)posrednom kontaktu s tom životinjskom vrstom, stoga se u različitim kulturama razvio složen odnos prema njoj. U većini religijskih, mitoloških, folklornih i simboličkih konteksta riba se obično pojavljuje kao opći pojam (više u Biedermann 1992; Royt i Šedinová 2001; Chevalier i Gheerbrant 2007 i dr.), a imenovanje pojedinih ribljih vrsta uglavnom je karakteristikom kultura čiji pripadnici žive od riba i ribolova (Ladan 2006). Zanimljivo je da se ni u temeljnom tekstu europskoga kulturnog i civilizacijskog kruga - Bibliji - ne vrši specifikacija ribljih vrsta, nego starozavjetna i novozavjetna predaja u prvom redu govore o ribi općenito (Ladan 2006). U vrijeme progona kršćana u Rimskom Carstvu riba je štoviše postala i kršćanskim simbolom, a ihtis, kao akronim za izraz Isus Krist, Božji Sin, Spasitelj, korišten je u identifikacijske svrhe. 
Antropocentričnost se jezične slike svijeta, između ostaloga, ogleda i u animalističkoj frazeologiji i to u vidu uglavnom stereotipnoga pripisivanja ljudskih karakteristika životinjskim vrstama (usp. npr. Bertoša 1999). Navedeno potvrđuju i frazemi $\mathrm{s}$ ihtionimskom sastavnicom u hrvatskom i slovačkom jeziku, u kojima se, na temelju empirijskoga iskustva, odnosno, poznavanja glavnih obilježja i ponašanja određenih ribljih vrsta, ali i kulturnih predodžbi i vjerovanja o njima, uspostavljaju i održavaju metaforičke veze između ljudskih i ribljih karakteristika.

\subsection{Ekvivalencija frazema sa sastavnicom riba}

Iako negdje dominiraju slatkovodne, drugdje morske ribe, u frazeološkim fondovima mnogih jezika ipak je veliki broj jedinica koje za sastavnicu imaju nespecificiranu riblju vrstu, odnosno, hiperonimsku komponentu riba. Čestim su izvorom slikovitosti takvih frazema razlikovna obilježja svih ribljih vrsta, poput specifičnoga prirodnog staništa, karakterističnoga dišnog sustava, načina kretanja i sl. Nerijetko su posrijedi internacionalni frazemi motivirani antropocentričnim uspostavljanjem analogija između općih ribljih karakteristika i ljudskoga ponašanja (usp. npr. Ljubičić i Kovačić 2008).

Uz vodu, kao prirodno stanište riba, u obama se jezicima veže nekoliko frazeoloških jedinica. Hrvatski poredbeni frazem osjećati se (biti, snalaziti se itd.) kao riba u vodi odnosi se na čovjeka, koji se nalazi u povoljnim uvjetima ili poznatoj okolini, što mu omogućava da se osjeća sigurno i dobro, a u slovačkoj mu je frazeologiji potpuno ekvivalentan razgovorni oblik byt' ako ryba vo vode (G). U uspoređivanim su jezicima također frekventne i antonimne strukture, hrvatski frazem osjećati se (biti itd.) kao riba na suhom označava čovjeka u nepovoljnim okolnostima, koji se ne osjeća dobro i ima određene poteškoće, a u slovačkom mu jeziku potpuno odgovara jedinica byt' (mat'sa i sl.) ako ryba na suchu. U slovačkoj frazeologiji zabilježena je i polisemna jedinica hádzat' sa ako ryba na suchu, u čijoj je dubinskoj slici reakcija ribe na novonastale, nepovoljne uvjete na kopnu kao neprirodnoj sredini za život. Ovisno o kontekstu, ovaj se frazem koristi kada se govori o (i) nemirnom čovjeku, ili o (ii) čovjeku koji nastoji izići iz teške situacije.

Sljedeća skupina frazema motivirana je načinom kretanja riba u vodi. U obama se jezicima sposobnosti izvrsnoga plivača najčešće uspoređuju s ribljim kretanjem, usp. plivati kao riba - plávat' ako ryba. Hrvatski frazem učiti ribu plivati (Ljubičić i Kovačić 2008: 201) značenja 'raditi nepotrebnu stvar' u slovačkoj frazeologiji ima samo semantički ekvivalent nosit' (vozit') drevo do hory (lesa) ili liat' vodu do mora (do Dunaja). Na ovom mjestu mogu se spomenuti i slovačke paremiološke jedinice s komponentom riba, koje imaju blisku semantiku, odnosno, značenje uzaludnoga truda, npr. v povetrí darmo chytat' ryby; ryby po strome lapá; vtáka na udicu a ryby na lep chytá. Za neke je vrste riba tipično iskakivanje iznad razine vode, što je motivacijom slovačkoga poredbenog frazema skočit' ako ryba značenja 'fleksibilno skočiti'.

U hrvatskom mu je jeziku djelomično ekvivalentan frazem s maritimnom animalističkom sastavnicom i iterativnim aspektom glagolske sastavnice skakati kao dupin (Ljubičić i Kovačić 2008: 193). Slika kretanja ribe prisutna je i u kulturno specifičnom 
hrvatskom dijalektnom frazemu skupljat se ka ribe na sviću koji reflektira priobalnu tradiciju noćnoga ribolova.

Sljedeća antropocentrična atribucija koja se reflektira u frazeološkim fondovima mnogih jezika jest ona o nijemosti riba. Budući da se zvučni signali u vodi šire drugačije, od davnine datira stereotipna predodžba o ribljoj šutljivosti. Iako mnogobrojna recentna istraživanja potvrđuju postojanje određenih oblika komunikacije među pojedinim ribljim vrstama, najčešće u vidu zvučne signalizacije u funkciji reprodukcije ili zastrašivanja predatora, antropocentrični stereotip o nijemim, odnosno, negovorećim ribama duboko je ukorijenjen u internacionalnom frazeološkom fondu. Navedeno potvrđuju i poredbeni frazemi dvaju kontrastiranih jezika šutljiv (nijem) kao riba - nemý ako ryba te šutjeti kao riba - mlčat' ako ryba koji se odnose na nerazgovorljiva čovjeka. Osim formalne podudarnosti i istovjetne slikovitosti, polisemni glagolski frazemi, značenja (i) 'ne reći ni riječi, uporno šutjeti' te (ii) 'znati čuvati tajnu', bivaju i semantički ekvivalentnima.

Neugodan miris karakterističan za ovu životinjsku vrstu motivacijom je hrvatskoga frazema riba smrdi od glave $<$ a čisti se od repa $>$, koji za razliku od slovačkoga oblika od hlavy ryba smrdí, sadrži i fakultativno proširenje. Osnovno frazeološko značenje 'krivnju treba tražiti kod rukovodećih', u hrvatskome je primjeru dopunjeno konstatacijom o neprovođenju toga načela u praksi. U ovome je primjeru posrijedi djelomična ekvivalencija uvjetovana strukturnom neistovjetnošću (premetanje i proširenje). Na temelju morfoloških razlika u (bes)prijedložnoj konstrukciji, djelomičnim se ekvivalentima smatraju i frazemi riba i gost treći dan smrde i ryba a host' na tretí den̆ smrdí, koji se pojavljuje i u obliku host' a ryba na tretí den̆ smrdí. U oba je slučaja posrijedi jezična petrifikacija analogije između neugodna olfaktornog iskustva i percepcije dugotrajna posjeta. Hrvatski poredbeni frazem smrdjeti kao riba u slovačkom jeziku nema ekvivalent s jednakom slikovitošću, nego mu je, kao i u hrvatskoj animalističkoj frazeologiji, bliska struktura s komponentom tvor, usp. smrdiet' ako tchor.

Riba kao prehrambena namirnica u srodnim se nacionalnim kulturama smatra izvorom zdravlja i vitalnosti, što je uvjetovalo simbolizaciju usidrenu u poredbenim frazemima zdrav kao riba i zdravý ako ryba koje predstavljaju apsolutne ekvivalente. U slovačkoj se frazeologiji pak komponenta $r y b a$ često nadomješta deminutivnim oblikom rybička, usp. zdravý ako rybička. S obzirom na različitu tvorbu, frazem s deminutivnim oblikom predstavlja djelomični ekvivalent ishodišnom hrvatskom frazemu. Za označavanje svježe, odmorne osobe koriste se frazeološke poredbe svjež kao riba i čerstvý ako $r y b a$, koje također predstavljaju apsolutne ekvivalente. U slovačkoj se frazeologiji koristi i poredbeni frazem byt' ako rybka (rybička), koji ima slično značenje 'biti svjež'. Slikom svježe uhvaćene ribe koja se, osim po mirisu, prepoznaje i po nezamagljenim, bistrim očima, motivirani su i danas manje frekventni frazemi vedro ka riblje oko i čistý ako <rybie> oko koji je zabilježen i u obliku čistý (jasný) ako rybie oko, čija je uporaba ograničena na opis vedroga neba ili mjeseca. U kontekstu ribe kao prehrambene namirnice pojavljuje se i hrvatski dijalektni frazem ka lešana riba [govori, izgleda, reagira i sl.] značenja 'bezvoljno, tromo [djelovati]' koji je motiviran obilježjima termički obrađene namirnice. 
Stariji hrvatski frazem sa strukturom rečenice velika riba malu jede, koji pod utjecajem suvremenih društvenih zbivanja doživljava stanovitu uporabnu revitalizaciju, danas je frekventniji u obliku velika riba jede malu. U slovačkom su im jeziku djelomično ekvivalentni arhaični frazemi vel'ké ryby malé zožierajú, odnosno, vel'ké ryby žerú malé. Ovim se frazemima izražava uvjerenje o supremaciji moćnika nad slabijima, koje je moglo biti podjednako aktualno i u razdoblju feudalizma kao i danas. U današnjoj su publicistici, prije svega u političkom i gospodarskom diskursu, ustaljene leksičke sveze krupna riba, odnosno, velika riba - velká ryba (G) u značenju 'utjecajna, moćna osoba', kao i antonimni frazemi sitna riba - malá ryba (G) koji se odnose na beznačajnoga čovjeka bez ikakva utjecaja. ${ }^{5}$ Noviji hrvatski frazem uhvatiti (uloviti) krupnu (veliku) ribu u prvom je redu povezan s otkrivanjem korupcijskih skandala u političkim krugovima te se koristi u značenju 'pritvoriti političara zbog korupcije' (Kovačević i Ramadanović 2013: 330). U slovačkom se jeziku sveza ulovit' vel'kú rybu (G) počinje sve češće pojavljivati u sportskoj publicistici za označavanje kupovine igrača koji bi sportskom klubu trebao osigurati dobre rezultate.

\subsection{Ekvivalencija frazema sa sastavnicom naziva slatkovodne ribe}

Slatkovodne ribe predstavljaju široku paletu jedinki, koje se međusobno razlikuju prvenstveno prema vanjskim obilježjima, poput oblika, veličine i boje tijela, zatim tipičnoga načina kretanja, prilagođavanja okolini i sl. Dominantne karakteristike pojedinih slatkovodnih ribljih vrsta temeljem su slikovitosti i motivacijom različitih frazeoloških jedinica u obama kontrastiranim jezicima, ali u znatno manjoj mjeri nego ustaljene strukture s hiperonimskom komponentom riba.

Gospodarski najznačajnijom i najraširenijom slatkovodnom ribljom vrstom jest šaran, koji poglavito nastanjuje jezera ili se pak uzgaja u umjetnim ribogojilištima. Zbog dugotrajnoga uzgoja prilagodio se boravku u stajaćim vodama i to prvenstveno povišenom građom tijela. Budući da pliva sporije od drugih vrsta, može ostaviti dojam lijenosti i apatičnosti, što se naposljetku i reflektira u frazeološkoj svezi šaranski mir, koja predstavlja određenu komotnost, tromost i pasivnost sredine. U slovačkom joj je jeziku značenjski blisko metaforičko imenovanje čovjeka izrazom kapor. Nasuprot toga, izraz štuka ima značenje 'agilni čovjek', a sveza byt' štukou 'biti neočekivano inicijativan, uspješan'. Obje riblje vrste dominantnim su predatorima u stajaćim vodama gdje, skrivajući se među vodnim raslinjem, vrebaju plijen, međutim, za razliku od šarana, štuka ima vretenasto tijelo koje joj omogućava brže kretanje. Upravo potonje obilježje stoji u pozadini motivacije hrvatskoga frazema štuka u ribnjaku, koji značenjem 'osoba koja mobilizira pasivnu sredinu' predstavlja značenjsku opoziciju svezi šaranski mir. Njenim djelomičnim ekvivalentom je slovački rečenični

Iako se može pretpostaviti da je recentna uporaba navedenih izraza pod utjecajem kalkiranja jedinica karakterističnih za anglofone publicističke diskurse, zanimljiva je i njihova prisutnost u starijim slovačkim poslovicama navedenima u zbirci Zátureckog, npr. z malej vody malé ryby (2005: 240); vel'ká voda, vel'ké ryby; malá voda, malé ryby (2005: 233). 
frazem prišla štuka medzi kaprov, koji je, osim sukladnom semantikom, obilježen i sličnom slikovitošću.

Iznimno pokretljivu vrstu slatkovodne ribe predstavlja piškor. Osim što povremeno može udisati atmosferski zrak, posebnost ove vrste jest i živo kretanje na površini vode koje obično navještava nagle vremenske promjene. Specifičan način kretanja vjerojatno je uvjetovao i nastanak hrvatskoga poredbenog frazema kao piškor u loncu, kojim se opisuje nemirna osoba koja se neprestano kreće zbog određene neugodnosti ili dosade. U slovačkoj frazeologiji ova jedinica ima djelomični ekvivalent hniezdit'sa (vrtiet'sa) ako hus (sliepka) na vajciach. U slovačkom jeziku zabilježen je i poredbeni frazem opitý ako č́k $k^{6}$, čija je slikovitost također utemeljena na specifičnom kretanju ove riblje vrste koje pokazuje stanovitu sličnost s neuravnoteženim kretanjem pijanih ljudi.

U hrvatskom mu je jeziku djelomično ekvivalentna jedinica pijan kao smuk za koju je, osim različite animalističke sastavnice, karakteristično i slično asocijativno povezivanje kretanja alkoholizirane osobe s uvijanjem tipičnim za zmije. Zmijoliko, sklisko tijelo jegulje motivacijom je i nekoliko hrvatskih frazema, poput izmicati kao jegulja koji se odnosi na ponašanje (i) brze i okretne osobe ili (ii) osobe koja izbjegava odgovornost, a kojemu je u slovačkom jeziku bliskoznačna sveza človek ako úhor, zatim ljigav kao jegulja kojemu je zbog razlike u pridjevskoj sastavnici djelomično ekvivalentna ustaljena poredba klzký ako úhor, kojom se označava neprincipijelan čovjek.

Hrvatski poredbeni frazem zijevati kao som, kojim se ekspresivno izražava intenzivno zijevanje zbog pospanosti ili dosade, ima djelomični ekvivalent u slovačkoj svezi s drugačijom animalističkom sastavnicom, naime, komponentom nilski konj - zivat' ako hroch. U dijalektnoj frazeologiji zabilježen je i frazem zijevati kao riba na suhom (Kovačević i Ramadanović 2013: 330), koji se, za razliku od prethodnoga, ne odnosi na intenzitet i uzrok zijevanja, nego opisuje stanje čovjeka koji iz određenih razloga ostaje bez riječi.

\subsection{Ekvivalencija frazema sa sastavnicom naziva morske ribe}

Kao što je naznačeno u uvodnome dijelu rada, kontrastivna analiza hrvatskih i slovačkih frazema koji za sastavnicu imaju naziv morske ribe, pokazuje razmjerno visok stupanj razilaženja. Dok je svega nekoliko različitih vrsta morskih riba zastupljeno u frazeologiji dvaju standardnih idioma, od kojih se u oba jezika pojavljuju samo frazemi $\mathrm{s}$ ihtionimskom sastavnicom sardina, odnosno, sardinka, što se u prvome redu može objasniti posvemašnjom dostupnošću te prehrambene namirnice, kao posljedica isprepletenosti priobalnih jezičnih (mikro)zajednica s maritimnom sastavnicom hrvatske kulture, u frazeološkim korpusima hrvatskih priobalnih govora, poglavito čakavskih, bilježi se veći broj jedinica motiviranih složenim odnosom lokalnoga stanovništva pre-

\footnotetext{
U suvremenom se slovačkom jeziku navedena frazeološka jedinica odnosi na jako alkoholiziranoga čovjeka. Pritom je zanimljivo da, zbog stanovite semantičke netransparentnosti, govornici uopće ne znaju da se leksem čik (lat. Misgurnus, hrv. piškor) zapravo odnosi na vrstu ribe, te ga štoviše ni ne shvaćaju kao imenicu. Ovaj se frazem, dakle, koristi bez poznavanja semantike sastavnice u C-dijelu poredbene strukture.
} 
ma određenim vrstama morske ribe. Uglavnom su posrijedi poredbeni frazemi u kojima se uspostavljaju antropocentrističke analogije između ljudskih fizičkih i karakternih osobina, emocionalnih stanja, percepcije prostora itd. i određenih karakteristika ribljih vrsta.

U splitskom se govoru emocionalno stanje ljutnje izražava kromatskim poredbenim frazemima s komponentom škarpina - crven ka škarpina i pocrvenit ka škarpina (Kovačević i Ramadanović 2013: 331). Takva konceptualizacija navedenoga (sklopa) osjećaja jednim je dijelom utemeljena na percepciji realne fiziološke reakcije, odnosno, pojavi crvenila uslijed povišenoga krvnog tlaka zbog stanovite emocionalne uzbuđenosti, a s druge je pak strane poduprta kulturno konstruiranom simbolizacijom crvene boje koja se najčešće povezuje s domenom snažnih, pozitivno ili negativno shvaćenih, kompleksa emocija (usp. npr. crveno kao simbol ljubavi i strasti, ali i bijesa i srdžbe). Osim što se odnose na manifestaciju emocionalnoga stanja, navedeni frazemi, kao i njihovi nadlokalni i nadregionalni oblici crven kao škarpina i pocrvenjeti kao škarpina, uz čakavski frazem carjen ko arbun, te neihtionimske jedinice šire uporabe crven kao rak (škamp) i pocrvenjeti kao rak (škamp), odnose se na crvenilo kože uslijed pretjeranoga izlaganja suncu. Ni jedna od navedenih jedinica, osim potonjih frazema červenýa ako rak te očerveniet' ako rak u slovačkom jeziku nema apsolutnoga ekvivalenta, ali zato postoji niz djelomično podudarnih sinonimnih poredbenih konstrukcija, koje u C-dijelu imaju značenjski udaljeniji leksem, a slijedom toga i drugačiju slikovitost, poput npr. červený ako paprika, očerveniet' ako paprika $\mathrm{i} \mathrm{dr}$.

Osim uspostavljanja paralela između ljudskih, emocionalno ili vanjskim utjecajima uvjetovanih, promjena boje kože i kromatskih obilježja određenih ribljih vrsta, u hrvatskom se frazeološkom fondu pojavljuje i niz drugih poredbenih frazema utemeljenih na analogijama između ljudske i riblje fizionomije, poput građen ka(o) cipal u značenju 'vrlo lijepo i skladno građena osoba', a u hvarskim govorima i bit ko (kako) gof antonimnoga značenja ‘biti nezgrapan, neskladno građen' (Kovačević i Ramadanović 2013: 331). Dominantno negativan aksiološki sud karakterističan za animalističku frazeologiju potvrđuju i pejorativni frazemi, koji su motivirani neobičnim oblikom određene riblje vrste i odnose se na sociokulturno nepoželjnu estetsku kategoriju te su, zbog gramatičkoga roda ihtionimske sastavnice, uglavnom ograničeni na ženske osobe: ružna kao grdobina (raža, škarpina) (Vidović Bolt 2011: 260). Kao i u ranijim primjerima, ni ovi frazemi u slovačkom jeziku nemaju potpunih, nego djelomičnih ekvivalenata, poput npr. škaredý ako noc i dr., koji su uglavnom dijelom i hrvatske frazeologije, ili pak škaredá (škaredý) ako ropucha (opica) (hrv. majmun).

Još jedna, kulturološki ambivalentna, a frazeološki negativno konotirana fizička karakteristika - mršavost, poimana kao osušenost, u hrvatskome se jeziku izražava poredbenim svezama intenzificirajućega značenja suh (mršav) kao bakalar i osušiti se kao bakalar, kojima su u slovačkome jeziku ekvivalenti s dijakronijskoga i frekvencijskoga stajališta djelomično podudaran frazem suchý ako haring, te leksički i motivacijski diferencirani chudý (vyschnutý, vysušený) ako trieska, odnosno, vyschnút' ako trieska, vyschnút' (vychudnút') na triesku. Za razliku od prijašnjih primjera, u ovome je slučaju posrijedi visoki stupanj frazeološke ekvivalencije, u kojem, uz neznatne formalne ra- 
zlike u tvorbi pridjevskih komponenti (neprefigirane hrvatske vs. prefigirane slovačke) A-dijela poredbenih frazema, nema nikakvih razilaženja u značenju i slikovitosti, kao ni u sociolingvističkoj i stilističkoj vrijednosti. Uz navedene, u hrvatskom se jeziku pojavljuje još nekoliko dijalektno markiranih frazema sa sastavnicama cipal i bakalar. $\mathrm{Na}$ srednjodalmatinskom govornom području izrazima stari cipal, odnosno, cipal iz (od) porta imenuje se snalažljiv i iskusan čovjek, dok frazemi biće bakalara (Split), čapat bakalara (Korčula), namlatiti koga kako bakalar (Crikvenica), motivirani tradicionalnom obradom te prehrambene namirnice, obično imaju pragmalingvističku funkciju zastrašivanja djece mogućom fizičkom kaznom zbog neprimjerna ponašanja (Kovačević i Ramadanović 2013: 332). U slovačkom jeziku ni s ovim potonjim frazemima nema potpuno podudarnih jedinica.

U hrvatskome se jeziku pojavljuju jedinice ni riba ni meso te ni pirka ni kanjac, kojima je djelomični ekvivalenti slovački frazem ani ryba ani rak u značenju 'nešto neodređeno'. Iako su slovački i hrvatski frazemi sinonimni, odnosno, značenjski potpuno podudarni, zbog različitih, manje ili više udaljenih, leksičkih sastavnica, imaju diferenciranu slikovitost, a time i različitu motivaciju. Dok je slika slovačkoga frazema utemeljena na supostavljanju nijekanja identificiranja određenoga entiteta s dvjema različitim vodenim životinjskim vrstama, prvi hrvatski primjer motiviran je isključivanjem srodnosti s dvjema sličnim prehrambenim namirnicama, a drugi s dvjema vrlo sličnim ribljim vrstama, koje priobalno stanovništvo ipak dobro razlikuje, što potvrđuju i dubinske slike frazema gledati kao kanjac značenja 'izbuljiti oči' te zinuti kao kanjac (u hvarskim govorima oči su mu iskočile ko (kako) konjcu na kančenici) značenja 'imati iznenađen izraz lica' utemeljene na prepoznatjivim izbuljenim očima koje pridonose „začuđenom“ izrazu navedene ribe (Kovačević i Ramadanović 2013: 333). U slovačkom se jeziku ovo značenje izražava animalističkim frazemom drugačije motivacije i slikovitosti hl'adiet' ako žaba z prachu. Za razliku od kanjca, pirka se kreće među stijenama u plićem moru što je motiviralo nastanak hrvatskoga frazema viriti kao pirka u značenju 'krišom gledati'. U slovačkom jeziku potonji frazem nema potpunoga ekvivalenta.

U hrvatskim dijalektnim frazeološkim fondovima zabilježeno je nekoliko jedinica $\mathrm{s}$ ihtionimskom sastavnicom salpa, motiviranih fizionomijom te morske ribe s dugim crijevima koja se hrani biljkama i izmetom, usp. npr. srednjodalmatinske pejorativne frazeme pun ka salpa govana značenja 'isprazno govoriti, biti pun sebe' s kojim je usko povezana ironična poredba pametan ka salpa u značenju 'glup' (Kovačević i Ramadanović 2013: 333). Slikovitost ovih frazema počiva u predodžbi ispunjenosti salpinih crijeva fekalijama, odnosno, na uspostavljanju paralele s nerazmjerom kvantitete i kvalitete izgovorenoga. Prvome je frazemu u slovačkom razgovornom jeziku značenjski bliska ekspresivna struktura mat' reči ako koza bobkov. Kvantitativni aspekt predodžbe salpina probavnoga sustava motivacijom je i frazema pun novaca (para) ko salpa govana značenja 'jako bogat čovjek' (ibid.).

Koncept prostorne stiješnjenosti u hrvatskom i slovačkom standardu izražava se potpuno ekvivalentnim frazemima zbijeni (stisnuti, nabijeni i sl.) kao sardine $<u$ konzervi $>$ - natlačeni ako sardinky, koji su, osim sukladnih leksičkih sastavnica i njihovih gramatičkih obilježja, motivirani i zajedničkom slikovitošću. Metaforička konceptualizaci- 
ja klaustrofobičnosti prostora kao stiješnjenosti konzerve eksplicirana u fakultativnom proširivanju strukture hrvatskoga frazema neznatno utječe na njegovu dubinsku sliku i nimalo ne mijenja njegovo značenje. U čakavskim i novoštokavskim ikavskim idiomima isto se značenje iskazuje djelomično ekvivalentnim frazemima nabiveni kako sardele, zbijeni kako srdele, ka slane srdele (Kovačević i Ramadanović 2013: 332), koji se od navedenih, osim različitim sociolingvističkim konotacijama i stilističkom vrijednošću, u određenoj mjeri razlikuju i dubinskom slikom utemeljenoj na tradicionalnoj recepturi čuvanja ribe, što je posebno izraženo u potonjoj strukturi s elidiranom pridjevskom sastavnicom A-dijela frazema i sintagmatskim proširenjem C-dijela. Osim frazema s komponentom sardina, u slovačkom jeziku bilježimo i dvije jedinice koje za sastavnicu imaju haringu - natlačeni ako haringy, koja je izvedena iz starijega proširenog oblika ležat' ako haringy $v$ sude nasolené a natlačené - $\mathrm{u}$ kojima bliskoznačni leksem za srodnu riblju vrstu, a u drugom primjeru i proširena struktura, tek neznatno mijenjaju slikovitost, ali ne utječu na frazeološko značenje. Još jednim od hrvatskih frazema koji ima djelomični ekvivalent u slovačkom jeziku jest ima ih ka sardel (Ljubičić i Kovačić 2008: 197) u značenju mnoštva koga ili čega, usp.je ich ako hadov (<červených> myši) (hrv. zmija).

Negativna stereotipizacija morskih pasa, uglavnom utemeljena na realističnim predodžbama o opasnim grabežljivcima, u slovačkom je jeziku izražena pejorativnim metaforičkim imenovanjem nezasitna, proždrljiva čovjeka leksemom žralok. Navedeno uspostavljanje analogije između ljudske osobine i određenih karakteristika morske nemani prisutno je i u poredbenom frazemu byt' pažravý ako žralok značenja 'biti jako proždrljiv', a do zanimljive frazeologizacije došlo je u ekonomskom diskursu, gdje sintagma finanční žraloci simbolizira bezobzirnu pohlepu, težnju za stjecanjem materijalnih dobara i privilegija kapitalističkih subjekata. Navedene jedinice nemaju potpunih ekvivalenata u hrvatskom jeziku.

\section{Zaključak}

Polazištem hrvatsko-slovačke frazeološke konfrontacije četverodijelna je tipologija ekvivalencije prema kriterijima (ne)istovjetnosti formalnih i semantičkih obilježja, ali i razine slikovitosti uspoređivanih frazeoloških jedinica. Korpus prikupljenih jedinica, koji poglavito čine ustaljene frazeološke poredbe, svjedoči o zastupljenosti svih osnovnih tipova ekvivalencije, dok provedena analiza s jedne strane potvrđuje pretpostavku o razmjernoj sukladnosti hrvatskih i slovačkih frazema s hiperonimskom sastavnicom riba, a s druge pak postojanje manjih ili većih kulturološki uvjetovanih razilaženja među strukturama s komponentom naziva određene slatkovodne ili morske ribe. Budući da su u prvom slučaju uglavnom posrijedi internacionalni antropocentrični poredbeni frazemi motivirani analogijama između određenih karakternih i bihevioralnih obilježja ljudi i prominentnih obilježja svih ribljih vrsta, u velikom broju takvih jedinica posrijedi je potpuna ili djelomična ekvivalencija s manjim ili većim leksičkim i/li gramatičkim odstupanjima. Za razliku od toga, značajnija odstupanja među frazemima koji za sastavnicu imaju određenu vrstu slatkovodne i posebno morske ribe, rezultiraju većim brojem čisto semantičkih ili nultih ekvivalenata. 


\section{LITERATURA}

Bertoša, Mislava. 1999. Stereotipi o životinjama. U: Teorija i mogućnosti primjene pragmalingvistike. Badurina, Lada; Ivanetić, Nada; Pritchard, Boris; Stolac, Dijana (red.). Rijeka - Zagreb: Hrvatsko društvo za primijenjenu lingvistiku. 63-76.

Biedermann, Hans. 1992. Lexikón symbolov. Bratislava: Obzor.

Čižmárová, Mária. 2001. Ekvivalenčné typy frazém v ukrajinčine a slovenčine. Slavica Slovaca. 2: 114-120.

Dobríková, Mária. 2010. Kultúrno-sémantické aspekty frazeologickej ekvivalencie. U: Preklad ako kultúrna a literárna misia. Kulihová, Alica; Škvareninová, Ol'ga (red.). Bratislava: Univerzita Komenského Bratislava. 88- 97.

Dolník, Juraj. 1999. Princíp ekvivalencie. U: Princípy stavby, vývinu a fungovania slovenčiny. Dolník, Juraj et al. Filozofická fakulta Univerzity Komenského. 45-77.

Durčo, Peter. 1989. Motivovanost' frazeologických jednotiek a typológia ekvivalentov. Jazykovedný časopis. 1: 33-41.

Fink, Željka. 2001. Hvatamo li za bradu Boga ili boga? O jednom pravopisnom problemu u frazeologiji. Filologija 36-37: 139-148.

Fink-Arsovski, Željka. 2002. Poredbena frazeologija: pogled izvana i iznutra. Zagreb: FF press.

Jankovičová, Milada. 2013. Ruská bezekvivalentná frazeológia: frazeologická teória a frazeografická prax. U: Philologica LXXI. Dobríková, Mária (red.). Bratislava: Univerzita Komenského v Bratislave. 187-195.

Kekez, Josip. 1996. Poslovice, zagonetke i govornički oblici. Zagreb: Matica hrvatska.

Korhonen, Jarmo. 2007. Probleme der kontrastiven Phraseologie. U: Phraseologie: Ein internationales Handbuch der zeitgenösischen Forschung. / Phraseology: An International Handbook of Contemporary Research. Burger, Harald et al. (red.). Berlin - New York: Walter de Gruyter. 574-589.

Kovačević, Barbara; Ramadanović, Ermina. 2013. Slika mora u hrvatskoj frazeologiji. U: $W a-$ ter in slavonic Phraseology and Paremiology. Zoltan, Andras; Fedosov, Oleg; Janurik, Sabol’č (red.). Budapest: Tinta. 329-335.

Krošláková, Ema. 1997. Frazeologické prirovnania so zoonymickým komponentom. U: Frazeolofické štúdie II. Ďurčo, Peter (red.). Bratislava: Esprima. 103-112.

Ladan, Tomislav. 2006. Etymologicon. Zagreb: Masmedia.

Ljubičić, Maslina; Kovačić, Vinko. 2008. Alcuni ittionimi nella fraseologia croata. U: Lenguaje figurado y motivación. Una perspectiva desde la fraseología. Álvarez de la Granja, María. (red.). Frankfurt am Main: Peter Lang. 191-207.

Menac, Antica; Menac-Mihalić, Mira. 2013. More u hrvatskoj frazeologiji. U: Frazeološka simfonija: Sodobni pogledi na frazeologijo. Jakop, Nataša; Jemec Tomazin, Mateja (red.). Ljubljana: Inštitut za slovenski jezik Frana Ramovša. 135-144. 
Menac-Mihalić, Mira; Menac, Antica. 2011. Frazeologija splitskoga govora s rječnicima. Zagreb: Institut za hrvatski jezik i jezikoslovlje.

Meršić, Žuža; Krekić, Tomislav. 2011. Prilog kontrastivnoj analizi hrvatskih i mađarskih frazema. Studia Slavica Savariensia 1-2: 229-238.

Mlacek, Jozef. 2008. O podnetoch súčasnej frazeologickej teórie na preklad a translatológiu. U: Letná škola prekladu 6. Keníž, Alojz (red.). Bratislava: AnaPress. 23-39.

Mlacek, Jozef et al. 1995. Frazeologická terminológia. Bratislava: Stimul.

Nedkova 2003 = Недкова, Емилия. 2003. Фразеологично богатство в творчеството на Алеко Константинов. Русе: ЛЕНИ-АН.

Royt, Jan; Šedinová, Hana. 2001. Slovník symbolů. Praha: Mladá fronta.

Skladaná, Jana. 1993. Frazeologický fond slovenčiny v predspisovnom období. Bratislava: VEDA.

Vidović Bolt, Ivana. 2004. Frazemi sa zoonimskom sastavnicom u poljskom i hrvatskom jeziku. Doktorska disertacija. Filozofski fakultet. Sveučilište u Zagrebu. Zagreb.

Vidović Bolt, Ivana. 2011. Frazeološki majstori s mora (o hrvatskim maritimnim frazemima). U: Slavenski jezici u usporedbi s hrvatskim II. Sesar, Dubravka (red.). Zagreb: FF press. 253-263.

Záturecký, Adolf Peter. 2005. Slovenské príslovia, porekadlá, úslovia a hádanky. Bratislava: Slovenský Tatran.

\section{RJEČNICI}

Anić, Vladimir. 2003. Veliki rječnik hrvatskoga jezika. Zagreb: Novi Liber.

Chevalier, Jean; Gheerbrant, Alain. 2007. Rječnik simbola: mitovi, snovi, običaji, geste, oblici, likovi, boje, brojevi. Zagreb: Kulturno-informativni centar - Naklada Jesenski i Turk.

Fink Arsovski, Željka et al. 2006. Hrvatsko-slavenski rječnik poredbenih frazema. Zagreb: Knjigra.

Krátky slovník slovenského jazyka. 2003. Kačala, Ján; Pisárčiková, Mária; Považaj, Matej (red.). Bratislava: Veda.

Matešić, Josip. 1982. Frazeološki rječnik hrvatskoga ili srpskog jezika. Zagreb: Školska knjiga. Matković, Dinko. 2004. Rječnik frazema i poslovica govora Vrboske na otoku Hvaru. Jelsa: Ogranak Matice hrvatske Jelsa.

Menac, Antica; Fink-Arsovski, Željka; Venturin, Radomir. 2003. Hrvatski frazeološki rječnik. Zagreb: Naklada Ljevak.

Slovnik slovenského jazyka. 1959-1968. Peciar, Štefan (red.). Bratislava: Vydavatel'stvo Slovenskej akadémie vied.

Smiešková, Elena. 1988. Malý frazeologický slovník. Bratislava: Slovenské pedagogické nakladatel'stvo. 


\section{ZHRNUTIE}

\section{TYPOLÓGIA FRAZEOLOGICKEJ EKVIVALENCIE NA PRÍKLADE CHORVÁTSKYCH A SLOVENSKÝCH FRAZÉM S ICHTYONYMICKÝM KOMPONENTOM}

Na základe typológie medzijazykovej ekvivalencie spracovanej v chorvátskej a slovenskej frazeológii v príspevku sa vyčleňujú jej druhy, ktoré sa demonštrujú na príkladoch chorvátskych a slovenských frazém s ichtyonymickým komponentom. Vzhladom na mieru ich vzájomnej zhody v rámci štruktúrnych, sémantických, funkčno-štylistických a i. vlastností rozlišujú sa štyri základné typy frazeologickej ekvivalencie: absolútne ekvivalenty, parciálne ekvivalenty, výlučne semantické ekvivalenty a bezekvivalentné frazémy. Popri viacúrovňovej analýze medzijazykovej ekvivalencie vybraného frazeologického korpusu pri posudzovaní frazeologických fondov s ichtyonymickým komponentom chorvátskeho (mediteránske, maritímne) a slovenského (stredoeurópske, kontinentálne) jazykového spoločenstva sa zohladňujú aj kulturologicky podmienené rozdiely. Zatial' čo uvedenú kulturologickú diferencovanost' primárne reflektujú národne či lokálne špecifické frazémy s hyponymickým ichtyonymickým komponentom, respektíve frazeologické jednotky, ktoré vo svojom komponentovom zložení obsahujú názov konkrétnej morskej alebo sladkovodnej ryby, hyperonymické komponenty sa vyskytujú predovšetkým ako súčast' absolútnych alebo parciálnych ekvivalentov a internacionálnych frazém.

Kl'účové slová: frazéma, ichtyonymický komponent, ekvivalencia, chorvátska frazeológia, slovenská frazeológia 
